\title{
IDENTIFYING DISEASES OF GOLDEN JACKALS OF BANGLADESH AGRICULTURAL UNIVERSITY CAMPUS, MYMENSINGH, BANGLADESH
}

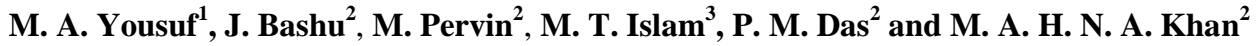 \\ ${ }^{1}$ Bangladesh Livestock Research Institute (BLRI), Savar, Dhaka, ${ }^{2}$ Department of Pathology, Faculty of \\ Veterinary Science, Bangladesh Agricultural University, Mymensingh-2202, Bangladesh, ${ }^{3}$ Department of \\ Pathobiology, Bangabandhu Sheikh Mujibur Rahman Agricultural University \\ Gazipur, Bangladesh
}

\begin{abstract}
Golden jackals is one of the semidomestic wild carnivors of the environment of Bangladesh Agricultural University (BAU) campus and now a days very often share spend their time with native dogs and cats in the gouse food wastes. This is not unusual for jackals to share diseases of dogs and cats. This study was aimed to identify important diseases of golden jackals and categorized to their zoonotic importance. A total of five apparently healthy golden jackals were collected from BAU campus and thorough postmortem examination was carried out during the period from July to December , 2010. Histopathological studies were conducted using routine Hematoxylin \& Eosin procedure. The existence of blood parasites were studied by Giemsa's staining. Polymerase Chain Reaction (PCR) \& Reverse Transcription-Polymerase Chain Reaction (RT-PCR) were adopted for the detection of tuberculosis (TB), canine distemper (CD) and avain influenza virus (AI). Other diseases investigated were liverfluke, whipworm, lungworm, mites and ascariasis. Out of five jackals examined, four were infected with heartworm Dirofilaria immitis. Gross examination of a Jackal at necropsy revealed nodular lesions in lungs and suspected as a case of TB. Acid fast staining and PCR protocol specific for TB could not detect mycobacterium in the nodular lungs lesions. Results of RT- PCR with the extracted RNA from liver showed amplification of 287bp fragment specific for CD viral infection in two cases. This is the first study in Bangladesh describing infection of CD in jackals. Jackals are scavanging in nature and reasonably AI could have present in jackals. RT-PCR protocol specific for matrix protein gene of AI viruses did not amplify any nucleic acid fragment . Results of this study showed that the golden jackals of BAU campus were infected with heartworm, lungworm, liverfluke, whipeworm, ascarids, mites and CD viruses. Extensive investigation is needed to explore the existance of few other important diseases of jackals including bovine and human TB, AI, leishmaniasis, $r$ abies, Toxoplasmosis, Infectious canine hepatitis, Taeniasis and Canine hookworm infestation. heartworm, whipworm and mites have zoonotic importance, therefore, it needs to develop stretagy to prevent their future dessimination in human and other animals.
\end{abstract}

Key Words: Jackals, PCR, RT-PCR, Histopathology, Heart worm, Canine distemper

\section{INTRODUCTION}

The integrative approach of wildlife conservation is important for human well being, domestic animal protection and eco-health. Among wild lives, Golden jackal has already entered in domestication processess at Bangladesh Agricultural University (BAU) campus, Mymensingh. Moreover, wild jackals, native dogs and cats are common scavangers at BAU campus . Foxes and jackals are similar wild carnivores, could carry and shares many parasitic and infectious diseases and could serve as a reserver of infection to human, domestic animals and other wild lives (Noble et al., 1989). A number of diseases already reported in foxes and jackals including mange, heartworm infestation (Mulley and Starr, 1984), intestinal nematodiasis (Malczewski, 1962), tuberculosis(TB), canine distemper (CD), leishmaniasis (Khan et al., 2012), infectious canine hepatitis (ICH), rabies and toxoplasmosis (Smith et al., 2003). As dogs, jackals and cats were found to eat in a same tale at BAU campus, it is not surprising to find diseases of dogs and cats in wild jackals. Until now limited study has been carried out to identify diseases of jackals at BAU campus. Keeping these things in mind, this study was designed to identify the etiology and or diseases of jackals at BAU campus. Traditional disease diagnostic methods, PCR and RT-PCR protocols specific for Mycobacterium bovis, CD and AI virus were adopted and used to detect these diseases in apparently healthy jackals of BAU campus. Accurate identification of these diseases in jackals would

*Corresponding e-mail address: hadikhan68@yahoo.co.uk 


\section{A. Yousuf and others}

enable us to know the epidemiology of these diseases and enabling ecohealth worker to adopt or design future preventive and control strategies.

\section{MATERIALS AND METHODS}

\section{Selection of animals and necropsy}

Randomly selected and apparently healthy five Golden jackles were collected from BAU campus and used in this study. Systemic dissection and investigations were carried out that includes examination of liver, lymph node, kidney, spleen, heart, lungs, brain and skin. The diagnosis of different diseases or disease conditions was made based on characteristic gross and microscopic lesions, results of Giemsa staining of impression smears and results of PCR and RT-PCR analysis.

\section{Gross and microscopic examination}

Following necropsy lungs, 1 iver, heart, kidney, lymphnodes, skin and spleen were collected from the jackles and fixed in $10 \%$ neutral buffered formalin. The $4-5 \mu$ tissues sectionions were stained with the hematoxylin and eosin (H\&E) and acid-fast staining (Luna, 1968). Presence of blood parasites were investigated by using thin smears from venous blood onto clean glass slides, fixed in ice cold methanol, air dried and staining with Giemsa's solution (Khan et al., 2012). The slides were washed in water, air dried and examined under a low (10x) and high power (40x and 100x) objectives. Special emphasis was given to identify the intranuclear or intracytoplasomic inclusion bodies in the impression smears of liver to identify the presence of CD viruses. Adult heart worms were placed on to a clean slide, added lactophenol cotton blue, another slide was placed over the slide and compressed. The mouth parts and posterior end of the parasite was examined at 10x and 40x objectives for the detection of the species of heartworm involved.

\section{PCR and RT-PCR detection of TB, CD and AI Extraction of genomic DNA}

Genomic DNA was extracted from suspected tissues by using locally adopted conventional method (Flaws and Buckingham, 2007). Briefly, 20mg grained tissue was taken in the microcentrifuge tubes containing $200 \mu \mathrm{l}$ cell lysis buffer and vortexed. The solution was centrifuged at $4000 \mathrm{~g}$ for $10 \mathrm{~min}$ to collect the supernatant. Equal volume of phenol chloroform isoamyl alcohol (25:24:1) was added to the supernatant and vortexed. Then the solution was centrifuged at $10000 \mathrm{~g}$ for $3 \mathrm{~min}$ and the top layer (about $90-100 \mu \mathrm{l}$ ) was collected. $10 \mu \mathrm{l}$ of $5 \mathrm{M} \mathrm{NaCl}$ solution were added onto the solution. $250 \mu \mathrm{l}$ ice cold absolute ethanol was added, incubated on ice for $30 \mathrm{mins}$, centrifuged at $13000 \mathrm{~g}$ for $10 \mathrm{~min}$ and the supernatant was discarded carefully. The pellet was desalted twice using $80 \%$ ethanol, air dried, $25 \mu \mathrm{l}$ of nuclease free water was used to dissolve the pellet and stored at $4^{\circ} \mathrm{C}$. The DNA samples were evaluated both quantitatively and qualitatively using spectrophotometer and agarose gel electrophoresis respectively. The oligonucleotide primers were selected from published literature ( Table 1) to detect infection with Mycobacterium bovis, $\mathrm{CD}$ and $\mathrm{AI}$ viruses.

\section{PCR detection of TB}

The PCR was carried out with $25 \mu \mathrm{l}$ reaction volume consisting of $10 \mathrm{x}$ Master Mix $\left(\mathrm{GeNei}^{\mathrm{TM}}\right.$ PCR Master Mix Kit), 20pmol primer in each , 300nmol DNA template and require volume of nuclease free $\mathrm{H}_{2} \mathrm{O}$. PCR amplification was performed in a thermal cycler (Master Cycler Gradient, Eppendorf, Germany). Briefly, the genomic DNA template was denatured at $98^{\circ} \mathrm{C}$ for $5 \mathrm{~min}$ before 30 cycle of amplifications including denaturation at $95^{\circ} \mathrm{C}$ for $1 \mathrm{~min}$, anneling at $56^{\circ} \mathrm{C}$ for $1 \mathrm{~min}$ and extension at $72^{\circ} \mathrm{C}$ for $1 \mathrm{~min}$. The final extension was acheived at $72^{\circ} \mathrm{C}$ for $10 \mathrm{~min}$ and the program was held at $4^{\circ} \mathrm{C}$. The amplified product were analysed in $1.5 \%$ agarose gel, visualized in an image documentation system (Cell Biosciences, Alphalmager HP, USA) and the images were captured.

\section{RT-PCR detection of CD and AI viruses Extraction of viral RNA}

Total RNA was extracted from the suspected tissue s using RNeasy mini kit (Qiagen, Germany) as per the manufacturer's instruction. Briefly, 20mg lungs or liver tissues were crushed on pistle and morter using liquid nitrogen, dispensed in eppendorf tube containing $600 \mu$ l PBS. RNeasy mini spin column as provided with the 
extraction kits were used and extracted RNA in 50 $\mu 1$ RNase-free water. The extracted RNA was evaluated both quantitatively and qualitatively using spectrophotometer and agarose gel electrophoresis. The oligonucleotide primers from published literature (Table 1) were used to detect CD and AI viruses using RT-PCR.

Two step RT-PCR techniques for the amplification of genomic RNA was carried out. Firstly the $r \quad$ everse transcription of the extracted RNA was performed using 1.7-2.0 $\mu$ g RNA /10 $\mu 1$ sample in a PCR tube. Oligo (dT) primer $1.0 \mu \mathrm{l}$ was added in each tube, incubated at $65^{\circ} \mathrm{C}$ for $10 \mathrm{~min}$ and than at room temperature for $2 \mathrm{~min}$. The tubes were spin briefly and $1.0 \mu 1$ RNase inhibitor, $1.0 \mu 1$ of $0.1 \mathrm{M}$ DTT, $4.0 \mu 1$ of RT Buffer $(5 \mathrm{x}), 2.0 \mu 1$ of $30 \mathrm{mM}$ dNTP mix, $0.5 \mu 1$ of Reverse Transcriptase and $1.0 \mu 1$ sterile water were added. The solution was mixed gently and incubated at $42^{\circ} \mathrm{C}$ for one hour. Finally the tube was treated at $95^{\circ} \mathrm{C}$ for $2 \mathrm{~min}$ to denature RNA-cDNA hybrids and spined briefly. The tubes were quickly placed on ice and stored at $-20^{\circ} \mathrm{C}$ until PCR amplification of genomic content was carried out.

In second step the PCR amplification was carried out with $25 \mu 1$ reaction volume consisting of 10x PCR buffer, $30 \mathrm{mM}$ dNTP mix, 20pmol primer of each, $0.2 \mu 1$ of Taq DNA Polymerase (GeNei ${ }^{\mathrm{TM}}$ RT-PCR Master Mix Kit), $300 \mathrm{ng}$ cDNA and nuclease free $\mathrm{H}_{2} \mathrm{O}$ to make $25 \mu \mathrm{l}$ reaction volume. Amplification of genomic DNA was performed in a thermal cycler (Master Cycler Gradient, Eppendorf, Germany). The PCR amplification was carried out with an initial denaturation at $94^{\circ} \mathrm{C}$ for 2 min before 30 cycles of amplification include denaturation at $94^{\circ} \mathrm{C}$ for $1 \mathrm{~min}$, anneling at $52^{\circ} \mathrm{C}$ for $1 \mathrm{~min}$ and extension at $72^{\circ} \mathrm{C}$ for $1 \mathrm{~min}$. The final extension was acheived at $72^{\circ} \mathrm{C}$ for $5 \mathrm{~min}$ and the program was held at $4^{\circ} \mathrm{C}$. The amplified product were analysed in $1.5 \%$ agarose gel using an image documentation system and the images were captured. The results of PCR and RT-PCR were analysed and interpreted accordingly.

Table 1. Specific primers, their sequences and size of PCR amplicons for the detection of M. bovis, CD and AI viruses in golden jackals

\begin{tabular}{llll}
\hline $\begin{array}{l}\text { Name of primers } \\
\text { and Disease }\end{array}$ & Sequence $\left(5^{\prime}-3^{\prime}\right)$ & Product Size & References \\
\hline BTBF & CAGGGATCCACCATGTTCTTTAGCGGGTTG & $600 \mathrm{bp}$ & Xiu et al., 2006 \\
BTBR & TGGCGAATTCTTACTGTGCCGGGGG & & \\
CDF & ACAGGATTGCTGAGGACCTAT & 287bp et al., 1999 \\
CDR & CAAGATAACCATGTACGGTGC & \\
AIMPF & TTCTAACCGAGGTCGAAACG & 232bp & Leslie et al., 2008 \\
AIMPR & ACAAAGCGTCTACGCTGCAG & & \\
\hline
\end{tabular}

\section{RESULTS AND DISCUSSION}

\section{Gross and microscopic examination}

At necropsy all the jackals appeared apparently healthy, containing thickened layer of whitish abdominal fat (Fig. 1a), healthy liver (Fig. 1b) and spleen (Fig. 1c).
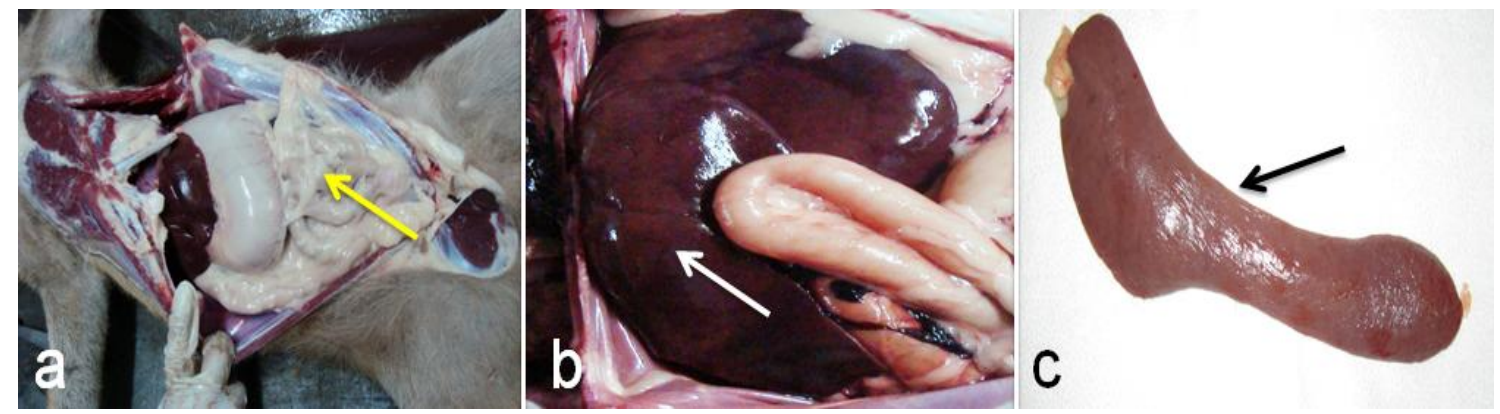

Fig. 1. Most of the jackals appeared apparently healthy at time of necropsy. The abdominal fat (a, yellow arrow) appeared bright white and shining, liver (b, white arrow) and spleen (c, black arrow) were healthy and did not reveal any visible lesion at time of necropsy. 


\section{A. Yousuf and others}

Grossly visible lesion was not seen on any of the visceral organs except a nodular lesion in lungs and mild hemorrghages in upper respiratory tract (Fig. 4a). The hemorrhages in upper respiratory tract was seen could be due to euthenesia or painless killing of the Jackals.

\section{Specific investigation of diseases Canine heartworm infestation}

Out of five jackals investigated, four $(80 \%)$ were found to infect with heart worm (Fig. 2). The parasites were seen in the right ventricle of heart and/or on the wall or in the pulmonary artery. The prevalence of heartworms (Dirofilaria immittis) infestation in foxes was reported in several countries (Mulley and Starr, 1984) but the prevalence of infection may vary with geographic location, habitat, densities of mosquito vectors and definitive hosts and climatic conditions (Wixsom et al., 1991). Our finding appeared similar with the report made by Mulley and Starr (1984); Wixsom et al. (1991); Marks and Bloomfield (1998). Thick blood smear obtained from the jackals at night and were stained with Giemsa's showed 6-7 microfilariae per 10x microscopic field (Fig. 2a and $2 \mathrm{~b}$ ). Jackals sacrificed at evening time and examined blood for microfilaria, revealed very few microfilarias in blood and it was due to periodicity of microfilaria related to heartworm infestation (Hinman, 1935).

The adult parasite was stained with lectophenol for species and sex determination (Fig. $2 \mathrm{~b}$ and $2 \mathrm{c}$ ). The female parasites were larger than the males. The males were 120 to $250 \mathrm{~mm}$ in length and $1 \mathrm{~mm}$ in diameter, possessed tails that were blunted, armed with caudal allae and were spirally coiled. The females were measured 250 to 310 $\mathrm{mm}$ in length and $1 \mathrm{~mm}$ in diameter and the vulva was situated near the posterior extremity of the esophagus. In infected Jackals o rganized thrombus was seen in the lungs resembling tuberculous lesions (Fig. 4b) and this could be due to dead heartworm infestation.

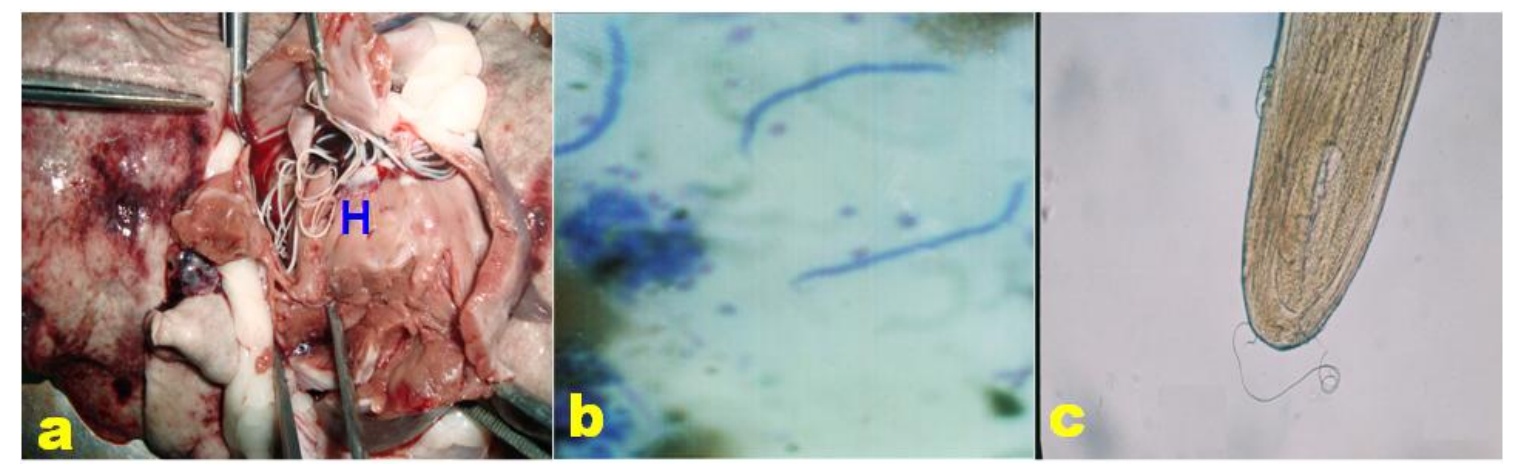

Fig. 2. Numerous heart worm $(\mathrm{H})$ Dirofilaria immitis found in the right ventricles of heart during necropsy (a). Peripheral blood collected at night and stained with Giemsa showed the presence of microfilaria (b, 10x) in the blood. The heart worm while examined under a microscope showed the presence of style at the caudal valley of the worm characteristics of Dirofilaria immitis (c, 40X).

\section{Ascariasis and whipworm infestation}

Ascariasis appeared as a common helminths in most domestic and wild canids. Canine ascarids Toxocara canis is a cosmopolitan nematode of many carnivores (Malczewski, 1962; Soulsby, 1965) is a well known parasite of dogs and may present in jackals (Skirnisson et al., 1993; Hiroshi et al., 1999). In this experiment, eggs of ascarid (Toxocara canis) were seen in the stool of two jackals. The appearance of egg was deep cup-like pits covering the surface of the shell (Fig. 3a). Egg of whipworm was seen in a jackal containing two knobs on its each side (Fig. 3b). The presence of w hipworm (Trichuris vulpis) in the caecum and colon of dogs was reported earlier (Richards and Lewis, 2001). Canine ascariasis (40\%) and canine whipworm infestation (20\%) were noted in golden jackals of BAU campus and the infestation could have earned from other canids living close proximity of jackals. 
Identifying diseases of golden jackals

\section{Lungworm and liverfluke infestation}

Lungworm (Crenosoma vulpis) was collected from the lower respiratory tract of jackal in this study. The parasite was milk-white in color, measuring $1-2$ inches in length and $1 \mathrm{~mm}$ in diameter (Fig. 3c). The lungs of infected jackal showed noteable infiltration of mononuclear cells in the lungs parenchyma, the alveoli were emphysematous and ruptured and presence of hemorrhages (Fig. 4a and $4 \mathrm{~b}$ ). In a case nodular lesion was seen in lungs (Fig. $4 \mathrm{~b}$ ) but the causes of granulomatous reaction could be due to heartworm infestation. The results of histopathological examination appeared similar with the findings of Bihr and Conboy (1999) and Nevarez et al., (2005). Out of five jackals investigated liver flukes infestation in the bile duct was seen in a case and the parasite could be Opisthorchis sp and most possibly Opisthorchis felineus. The flukes appeared creamy white in color, 4$5 \mathrm{~cm}$ long and $0.7-0.8 \mathrm{~mm}$ width (Fig. 3d). The liver of the infected jackal was necrotic, enlarged and congested. Schuster et al. (2001) reported $22 \%$ incidence of liver fluke infestation in dogs, the disease is also seen in human and but the lifecycle of the parasitic infestation in jackals is poorly understood.

\section{Lice and mites infestation}

Pediculosis was commonly seen in the dermis of jacklas of BAU Campus. Following close observation the skin of affected jackals appeared rough and shaggy; there was alopecia and usually marked pityriasis. In this study, haemorrhage, congestion and folliculitis were observed and it was due to mite infestation in the skin of scrotal region (Fig. 4c). Mite infestation especially Demodectic folliculorum is a common parasite in the dermis of dogs, served as active blood suckers and may caused death due to anaemia (Samad, 2000). The mange of jackals could easily be transmit to other carnivors of BAU campus and also could be transmitted to human being, require further investigation.
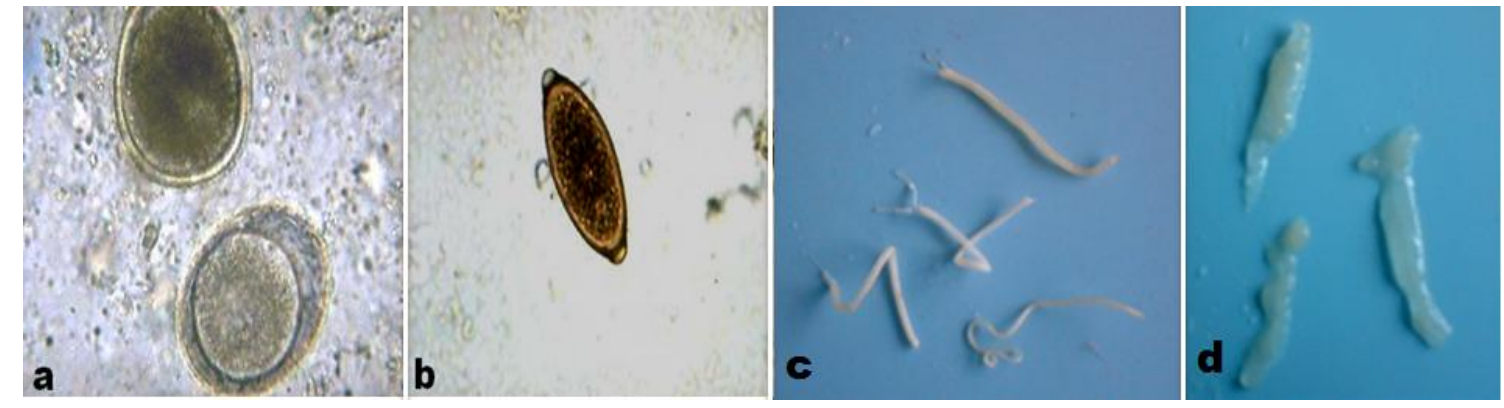

Fig. 3. Fecal sample collected from the dead jackals, filtered and diluted in PBS and prepared direct smear onto clean slide. Eggs of Toxocara sp. (a) and Trichuris vulpis (b) was seen under microscopic examination (40x). Adult lungs worm (c) from the upper respiratory tract and fluke (Opisthorchis felineus) from the bile ducts of liver (d) was also seen.

\section{Canine tuberculosis}

Following necropsy, several nodular lesions were seen in the lungs. The appearance of nodules was firm, white in color, presence of gray or yellow necrotic center. The section of a lung stained with H\&E reveled infiltration of mononuclear cells in the lungs parenchyma, the alveoli were emphysematous and ruptured and presence of excessive hemorrhages (Fig. 4b). Acid fast staining was failed to detect acid-fast organisms in the nodular lungs lesions. Genomic DNA extracted from lungs tissue and were subjected to PCR amplification of fragment of MPB83 gene of TB but did not amplify any genomic fragment (Fig. 5a) . It may be concluded that, the nodular lesions as seen in the lungs of jackal at BAU campus could be due to lungs worm or heart worm infestation . Jackals although served as a common scavanger at BAU campus it is reasonably expected to infect with TB from animals and birds but TB is uncommon in golden jackals of BAU campus.

\section{Canine distemper}

Canine distemper virus is a serious, often fatal disease of dogs and many other canids. The suspected lesion of $\mathrm{CD}$ virus was not seen during necropsy, following microscopic examination of impression smears of liver 


\section{A. Yousuf and others}

(inclusion bodies) and routine histopathological examination. However, while RT-PCR test protocol was applied with selected primer (Frisk et al., 1999) 287bp amplification was generated (Fig. 5b); this was specific for canine distemper viral infection but at subclinical level . RT- PCR assays for canine distemper virus offer substantial improvements in virus detection and thus may render easier the diagnosis of CD virus (Frisk et al., 1999; Messling et al., 1999; Shin et al., 2004 and Scott and Miller, 2007). It needs to sequence genomic dcontent of $\mathrm{CD}$ viruses and as well as to test large number of samples to know the epidemiology of CD pervailing in jackals of BAU campus.

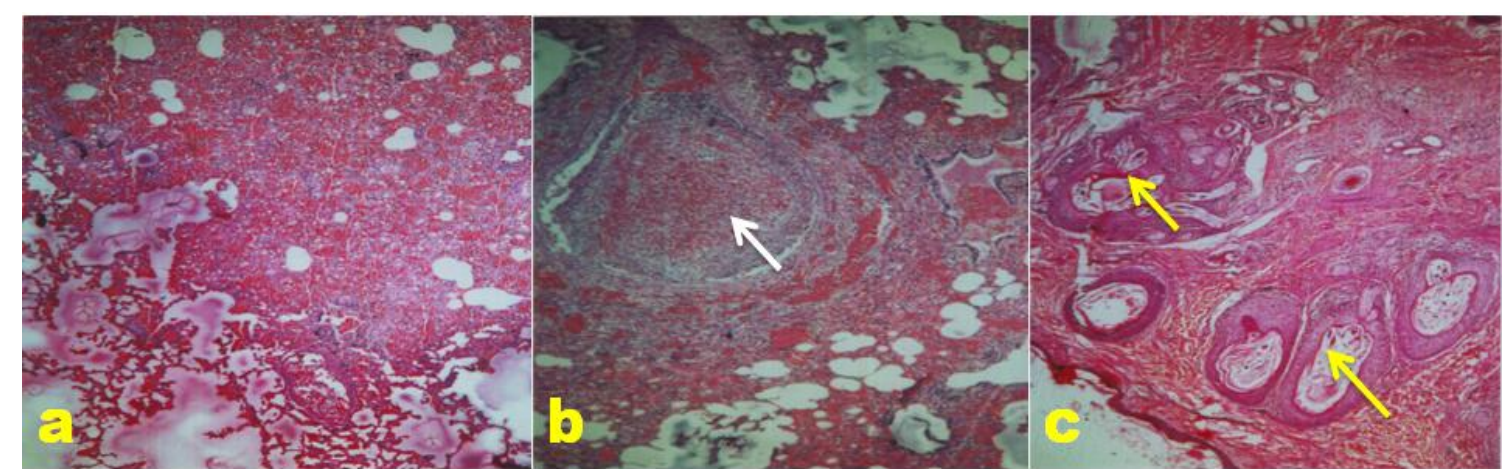

Fig. 4. Histopathologic examination of the lungs ( $a$ and $b$ ) and skin of jackals obtained at necropsy. Acute hemorrhagic lesin in the lungs (a) was seen due to acute death and respiratory distress of jackals. In a lungs nodular reaction (b, white arrow) characteristics of TB was seen. Mites infestation was commonly seen in the skin (c, yellow arrow) of jackals (H\&E, 10x).

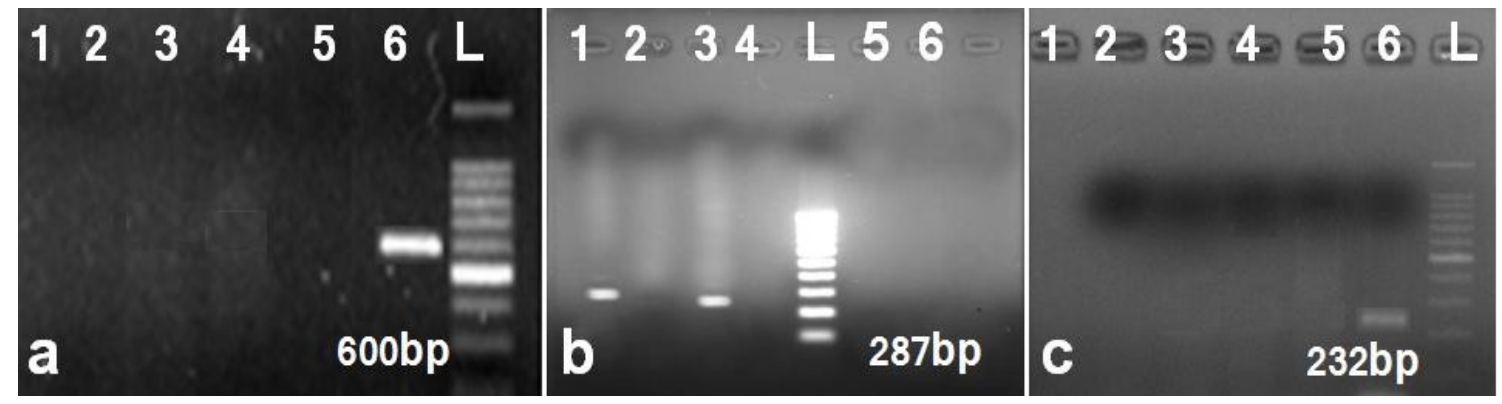

Fig. 5. PCR detection of M. bovis (a, 600bp amplicon) and RT-PCR detection of canine distemper (b, 287bp amplicon) and avian influenza (c, 232bp) viruses in the liver of golden jackals. Lane L is for 100bp ladder, lane 1 to 5 are for the test jackals and lane 6 was for known positive sample except for the canine distemper, which containing test sample for CD. Out of five jackles tested only two of them generated $287 \mathrm{bp}$ amplicon (b) specific for CD viruses.

\section{Avian influenza virus}

Wild carnivores (jackals) were at high risk of catching avian influenza (HPAI) virus due to its eating habit of infected wild and domestic birds as AI now a days is endemic in Bangladesh (Bari et al., 2009). Golden jackals are susceptible to infection with AI virus (Leslie et al., 2008). During necropsy and histological examination infiltration of reactive cells, excessive congestions and hemorrhages, and ruptured of lung alveoli were seen in lungs (Fig. 4a and 4b ). This study further aimed to detect (H5N1) avian influenza viruses from the lungs and trachea of golden jackals. However, specific amplicon (232bp) of AI viruses in the RT-PCR was not generated in this study. It did appear that the golden jackals of BAU campus was not infected with AI viruses. 
Identifying diseases of golden jackals

\section{CONCLUSIONS}

This study provides evidence that golden jackals of BAU campus were infected with heartworm, ascariasis, whipworm, lungworm, liverfluke, ascarids, mites and $\mathrm{CD}$ and detrimental for the livelihood of wild carnivores. The heartworm, ascariasis, whipworm, Ascarids ( Toxocara canis) and mites infestation generally possessed zoonotic threat. It needs to design research protocol to identify few more important diseases like tuberculosis, toxoplasmosis, infectious canine hepatitis, leishmaniasis, rabies, taeniasis and canine hook worm infestation and adopt future preventive and control stretagies accordingly.

\section{ACKNOWLEDGEMENT}

We are greatful to Bangladesh Agricultural University Research System (BAURES) for funding the research.

\section{REFERENCES}

1. Bari T, Islam MT, Pervin M, Happy SA, Chowdhury EH and Khan MAHNA (2009). Pathological and molecular investigation of avian influenza (AI) in layer chickens from field outbreaks. Bangladesh Veterinary Journal 43(14): 40-51.

2. Bihr T and Conboy GA (1999). Lungworm (Crenosoma vulpis) infection in dogs on prince Edward Island. Canine Veterinary Journal 40(8): 555-559.

3. Flaws ML and Buckingham L (2007). Common techniques in molecular biology. In: Molecular Diagnostics: Fundamentals, Methods, \& Clinical Applications Kindle Edition, F A Davis Company, Philadelphia, ${ }^{\text {st }}$ edn, p. 65 80.

4. Frisk AL, Konig M, Moritz A and Baumgartnerm W (1999). Detection of canine distemper virus nucleoprotein RNA by reverse transcription-PCR using serum, whole blood, and cerebrospinal fluid from dogs with distemper. Journal of Clinical Microbiology 37 (11): 3634-3643.

5. Hinman EE (1935). Studies on the dog heartworm, Dirofilaria immitis, with specific reference to filarial preriodicity. American Journal of Tropical Medicine 15: 371-383.

6. Hiroshi S, Takashi I, Yasushi I and Haruo K (1999). Parasitological survey on wild carnivore in North-Western Tohoku, Japan. Journal of Veterinary Medical Science 61 (9): 1023-1026.

7. Khan MAHANA, Khan SS, Bashu J, Rima UK, Pervin M, Hossain MZ, Habib MA, Chowdhury GA and Hossain MM (2012). Visceral leishmaniasis is endemic in golden jackals of Bangladesh Agricultural University campus, a threat for expanding future zoonotic visceral leishmaniasis. Bangladesh Journal of Veterinary Medicine 10 (1\&2): 97-105.

8. Leslie A, Reperant GA, Marco WG, Bildt GF, Rimmelzwaan AP, Dobson DA, Osterhaus ME and Thijs K (2008). Highly pathogenic avian influenza virus (H5N1) infection in red foxes fed infected bird carcasses. Emerging and Infectious Disease 230-250.

9. Luna LG (1968). Manual of Histologic Staining Methods of the Armed Forces Institute of Pathology. $3^{\text {rd }}$ edn. McGraw Hill Book Co., New York, USA.

10. Malczewski A (1962). Helminth parasites of red foxes and minks in Poland. Acta Parasitologica Polonica 10: 231260.

11. Marks CA and Bloomfield TE (1998). Canine heartworm (Dirofilaria immitis) detected in red foxes (Vulpes vulpes) in urban Melbourne. Veterinary Parasitology 78(2): 147-154.

12. Messling VV, Harder TC, Moennig V, Rautenberg P, Nolte I and Haas L (1999). Rapid and sensitive detection of immunoglobulin $\mathrm{M}$ (IgM) and IgG antibodies against Canine distemper virus by a new recombinant nucleocapsid protein-based enzyme-linked immunosorbent assay. Journal of Clinical Microbiology 37: 1049-1056.

13. Mulley RC and Starr TW (1984). Dirofilaria immitis in red foxes (Vulpus vulpes) in an endemic area near Sydney. Australian Journal of Wildlife Diseases 20(2): 152-153.

14. Nevarez A, Lopez A, Conboy G, Ireland W and Sims D (2005). Distribution of Crenosoma vulpis and Eucoleus aerophilus in the lung of free-ranging red foxes (Vulpes vulpes). Journal of Veterinary Diagnostic and Investment 17: 486-489.

15. Noble ER, Noble GA, Schad GA and Macinnes AJ (1989). The biology of animal parasites. Lea and Febiger, Philadelphia, Pennsylvania, p. 574.

16. Richards DT and Lewis JW (2001). Fecundity and egg output by Toxocara canis in the red fox (Vulpes vulpes). Journal of Helminthology 75(2): 157-164.

17. Samad MA (2000). Veterinary Practitioner's Guide. LEP Publication, BAU Campus; Mymensingh. $1^{\text {st }}$ edn, Bangladesh Veterinary Journal07: 308-335. 


\section{A. Yousuf and others}

18. Schuster RK, Heidrich J, Pauly A and Nöckler K (2007). Liver flukes in dogs and treatment with praziquantel. Veterinary Parasitology 150(4): 362-365.

19. Scott DW and Miller WH (2007). Juvenile cellulitis in dogs: a retrospective study of 18 cases (1976-2005). The Japanese Journal of Veterinary Dermatology 13(2): 71-79.

20. Skirnisson K, Eydal M, Gunnarsson E and Hersteinsson P(1993). Parasites of the arctic fox (Alopex lagopus) in Iceland. Journal of Wildlife Diseases 29 (3): 440-446.

21. Smith GC, Gangadharan B, Taylor Z, Hughes JM, Dinkel A, Romig T and Craig PS (2003). Prevalence of zoonotic important parasites in the red fox (Vulpes vulpes) in Great Britain. Veterinary Parasitology 118(1/2): 133-142.

22. Soulsby EJL (1965). Text book of veterinary clinical parasitology, Vol. I. Helminths. Blackwell Scientific Publications, Oxford, England, 1, p. 120.

23. Xiu-yun J, Wang C, Wang C, Zhang P and He Z (2006). Cloning and cxpression of mycobacterium bovis secreted protein MPB83 in Escherichia coli. Journal of Biochemistry and Molecular Biology 39(1): 22-25.

24. Wixsom MJ, Green SP, Corwin RM and Fritzell EK (1991). Dirofilaria immitis in coyotes and foxes in Missouri. Journal of Wildlife Diseases 27(1): 166-169. 